\title{
Using the Balanced Scorecard and the European Foundation for Quality Management Excellence model as a combined roadmap for diagnosing and attaining excellence
}

Marija Andjelkovic Pesic and Jens Jörn Dahlgaard

\section{Linköping University Post Print}

\section{Tweet}

N.B.: When citing this work, cite the original article.

This is an electronic version of an article published in:

Marija Andjelkovic Pesic and Jens Jörn Dahlgaard, Using the Balanced Scorecard and the European Foundation for Quality Management Excellence model as a combined roadmap for diagnosing and attaining excellence, 2013, Total Quality Management and Business Excellence, (24), 5-6, 652-663.

Total Quality Management and Business Excellence is available online at informaworldTM: http://dx.doi.org/10.1080/14783363.2013.791109

Copyright: Taylor \& Francis (Routledge): SSH Titles http://www.routledge.com/ 


\title{
Using the BSC and the EFQM EXCELLENCE MODEL as a combined Roadmap for Dignosing and Attaining Excellence
}

\author{
*Marija Andjelkovic Pesic \& **Jens J. Dahlgaard \\ *Corresponding author. \\ Willamette University, \\ Atkinson Graduate School of Management, \\ 900 State Street, Salem, Oregon, USA \\ marijaandjelkovic2003@yahoo.com; mandelko@willamette.edu \\ **Linköping University, \\ Department of Management \& Engineering \\ Linköping, Sweden
}

\begin{abstract}
:
The objective of the research presented in this paper is to identify relations and strength of relationships between elements of two models - the Balanced Scorecard (BSC) and the EFQM Excellence model. For that purpose a framework, which indicates the relationships between the mentioned models, has been developed. The hypothesis to be tested is whether the EFQM Excellence model may be used as an indicator of BSC implementation success. Hypothesis testing is based on data from a sample of 150 Serbian organizations. The results suggest that there are strong positive correlations between the BSC perspectives and the EFQM Excellence model criteria. Since the regression coefficients for the relationships between the BSC perspectives and the EFQM criteria are significant with high positive values the research results indicate a strong justification of the developed framework.
\end{abstract}

Key words: BSC model, EFQM model, perspectives, criteria, relationships.

\section{Introduction}

There is no magic recipe for providing a competitive advantage because competitive advantage is today mainly based on non-material resources. Due to that management systems have to include both financial and non-financial resources as well as appropriate objectives and measures to assure continuous improvements and optimization of the used resources. Financial objectives and measures of their achievement still represent significant indicators of success, but the achievement of such objectives depends on the achievement of a number of non-financial objectives which may be related to customers, processes and employees.

The connection between different objectives and measures of their achievement has been a motive for Norton and Kaplan to develop the BSC model (Kaplan \& Norton, 1992, 2000). The BSC enables managers to establish connections between objectives from different perspectives related to different stakeholders, to make such objectives obvious and more attainable (Kaplan \& Norton, 2006).

It is interesting that another model which explains possible relationships between enablers and results was presented in the same year as the BSC. The EFQM Quality Award model, which was introduced by the European Foundation for Quality Management in 1992 (Santos et al. 2007), includes the self-assessment criteria for achieving the European Excellence Award. The EFQM Quality Award model was renamed in 1998 to the European Excellence model signaling that quality is not sufficient for attaining excellence. 
While the BSC helps managers to identify objectives, measures and connections between them, the EFQM Excellence model is primarily used for assessment of an organization's success in the achievement of the objectives, or to check whether the organization is on the right track for attaining excellence.

When observed in this way, the BSC and the EFQM Excellence model may be considered as complementary models and therefore the questions that arise are: Do these models represent alternative ways for measuring and improving performances? Which one gives the best basis for management control (Dahlgaard, 2008)?

In order to provide answers to such questions one must familiarize with the characteristics of both models, identify relations between them and evaluate the level or significance of those relations.

\section{Managing and measuring business quality: The framework of research}

Some of the main characteristics of contemporary organizations are interconnection and interdependence between their organizational units as well as their employed individuals. Such characteristics imply the usage of comprehensive models for business management and performance measurements (Hogue \& James 2000). As there are several models to facilitate business management and performance measurements there seems to be a need or temptation to use more than one model (Goldratt \& Cox, 2004). One such possible use is the parallel application of BSC and the EFQM Excellence model.

A few authors have analyzed connections between the BSC and EFQM Excellence model. Shahin et al. (2012) tried to integrate those two business models while other authors tried to show the synergic effects of their parallel implementation (Lamotte \& Carter, 2000; Dror, 2008, Yang, 2009; Lua, Bettsa, \& Croom, 2011). However, Wongrassamee et al. (2003) adopted a critical attitude towards those models and suggested instead the adoption of strategic frameworks to specific types of organizations, since the BSC and EFQM model are considered as non-prescriptive models which they regarded as a weakness.

In the above mentioned researches the BSC and EFQM Excellence model were regarded as management tools with the same overall purpose. However, even if the BSC model includes measures of defined objectives in different perspectives, BSC is primarily a managerial tool intended for setting directions for an organization. The EFQM model, on the other hand, was primarily developed as a self-assessment tool intended for evaluation of efforts taken and the results achieved as a consequence of those efforts (Dahlgaard et al. 2013). However, gradually more and more successful organizations have learned how to extend the usage of the EFQM Excellence model to become a managerial tool for setting directions and for performance measurements like the BSC model - for example the Danish pump manufacturing company Grundfos (Dahlgaard \& Dahlgaard, 2008).

Today EFQM claims that (2012, p. 2):

"Whilst there are numerous management tools and techniques commonly used, the EFQM Excellence model provides a holistic view of the organization and it can be used to determine how these different methods fit together and complement each other. The model can therefore be used in conjunction with any number of these tools, based on the needs and function of the organization, as an overarching framework for developing sustainable excellence."

With this background, it is the research objective to analyze the relationships between the BSC and the EFQM Excellence model in order to discover the character and strength of the relationships between various levels of BSC implementation and results according to the EFQM model. 
The validity of the assumed relationships has been evaluated through analysis of empirical data collected from managers of Serbian organizations. The research is based on the assumption that the EFQM model can be implemented and used for evaluation of business performance in organizations that have already implemented the BSC model.

In order to accomplish the research objective the following framework has been created. This framework shows which EFQM model criteria are directly influenced by certain perspectives of BSC model (Figure 1).

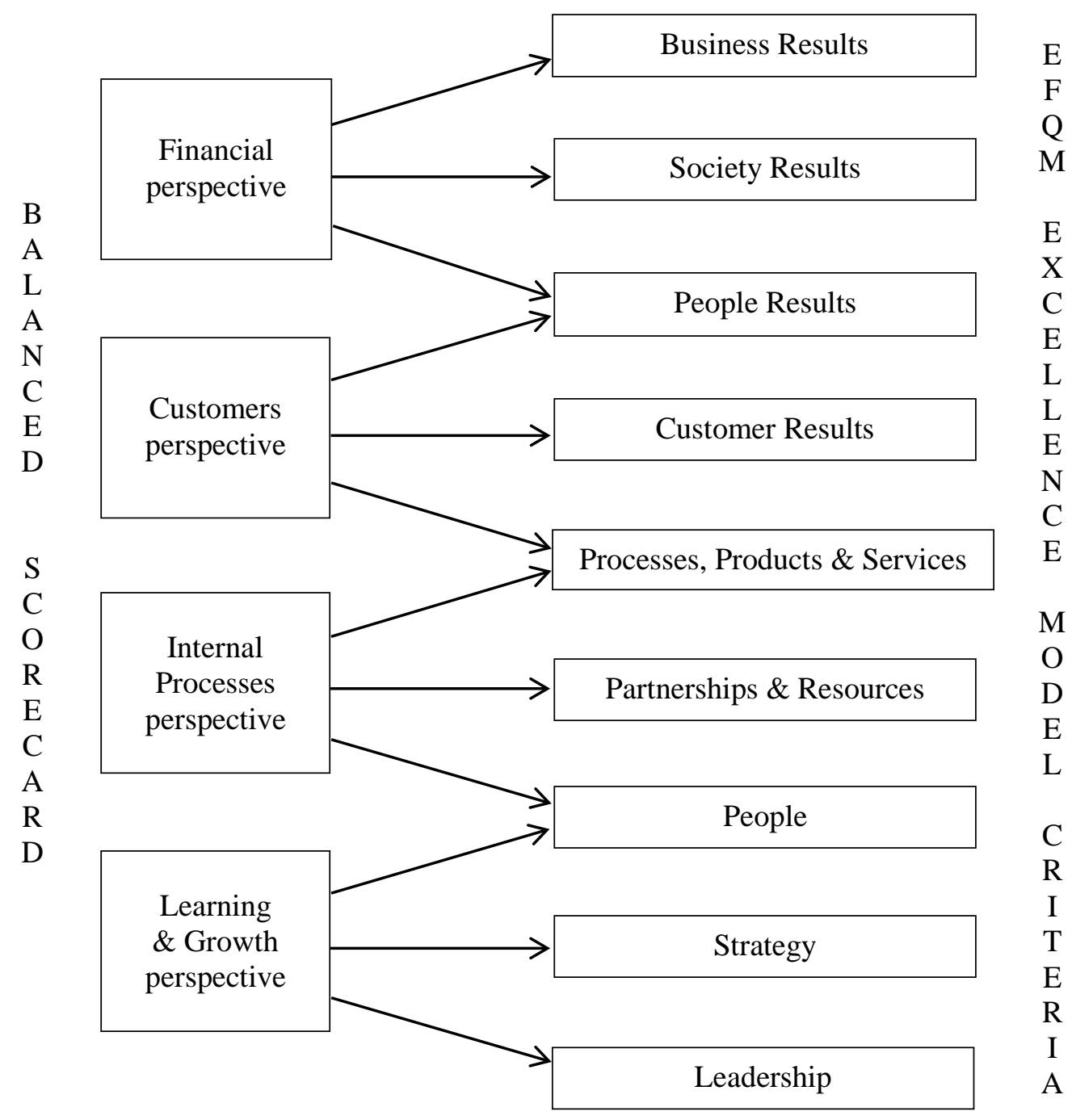

Figure 1: Framework of Relationships between BSC perspectives and EFQM model criteria.

As indicated in figure 1, the BSC model assumes a segmented management approach through four perspectives, and the establishment of cause-and-effect relationships between these perspectives (Davis \& Albright, 2004). The success in accomplishment of any defined objectives under the BSC model can be confirmed or denied through the appropriate criteria of the EFQM Excellence model. Seen through this lens, activities taken under the BSC perspective Learning and Growth reflect the EFQM Excellence model criteria Leadership, Strategy, and People. Success attained in the BSC perspective Internal Processes can be related to the following criteria of the EFQM Excellence model: People, Partnerships \& Resources, and Processes, Products and Services. Results achieved under the BSC Customer perspective reflect Processes, Products \& Services, Customer Results, and People Results, as 
criteria of the EFQM Excellence model. Finally, People Results, Society Results, as well as Business Results reflect the results of activities taken under the BSC Financial perspective. Hence, by using the framework in figure 1, the character and strength of relationships between the four BSC perspectives and the EFQM Excellence model may become apparent, so the research hypothesis is formulated as follows:

The EFQM Excellence model may be used as an indicator of a company's success or non-success with implementing the BSC.

The test of the above hypothesis is based on data measuring senior managers' perceived experiences from organizations in the Republic of Serbia that have used the BSC model for at least two years. The sample frame included organizations from a list of the 300 best companies in Serbia (according to the business revenue: www.proorg.fon.rs).

A questionnaire was filled out by managers of the 162 organizations which had used the BSC model for at least two years. However, only 150 senior managers fulfilled the whole questionnaires, and therefore only those data have been included into the analysis. Hence, the response rate in relation to the 162 companies which have used the BSC model for at least two years was as high as 92.6\%. Since the EFQM Excellence model has been observed as an assessment tool for evaluation of efforts and results achieved due to implementation of the BSC model, experience with the EFQM Excellence model was not a precondition for participating in the research. Managers of all companies (162) were familiar with the EFQM Excellence model, however only 57 have actually used it for self-assessment.

The analysis of the relationships in figure 1 is based on the evaluation of parameters and variables preceded from explanations of the BSC perspectives and the EFQM Excellence model criteria. The questionnaire comprised closed-type questions in the form of statements describing the perspectives and criteria elements of the BSC and EFQM Excellence model, respectively. Participants were asked to evaluate the statements related to their organization on a Likert scale from 1 to 5 , where 1 means that the interviewee completely disagrees with the statement and 5 that he/she completely agrees with the statement. Hence, the evaluation of the statements represents the respondents' perceptions of the level of presence/ implementation of each parameter or variable in their own organization.

Due to the fact that managers of the organizations in Serbia do not have data concerning society's satisfaction and that they did not want to comment on financial results of their organizations - the analysis included only seven criteria of the EFQM Excellence model. Therefore, since the evaluation of statements concerning the last two criteria of the EFQM model is missing, the financial perspective of the BSC model has also been excluded from the analysis. Hence, the analysis of the relationships between the BSC perspectives and the EFQM model criteria is based only on non-financial variables and parameters.

The first questionnaire (see Appendix A) concerns the BSC perspectives and includes five statements for each of the three analyzed perspectives: Learning \& Growth, Internal Processes, and Customers. The second questionnaire, which concerns the EFQM Excellence model criteria (see Appendix B), includes five statements for each of the seven analyzed EFQM criteria: Leadership, Strategy, People, Partnerships \& Resources, Processes, Products \& Services, Customer Satisfaction, and People Satisfaction. The statements for evaluation of the relationships between the EFQM Excellence model and the BSC model have been formulated based on previous published research (Lo, Wong, \& Cheung, 2006; Foster, 2004; Jou et al. 2007), and the final statements have been minor modified in order to be understood by the participating managers.

Data analyses have been carried out applying the logical thinking methods of induction, deduction and quantitative analysis tools - primarily statistical tools. The methods for data analyses used in the following pages were: Descriptive statistics, ANOVA, correlation and 
regression analysis. In order to provide comparability of results and conclusions, the methods used were the same as the ones used in the previously mentioned research studies.

\section{Research results}

In order to provide insight into the organizations' dedication to BSC and the EFQM Excellence model five statements for each of the 3 BSC perspectives and the 7 EFQM criteria have been defined. For the BSC model those statements are called variables (since in this research they are treated as enablers or factors), while for the EFQM model statements are called parameters (since they are treated as results, influenced by BSC perspectives).

To test the reliability of the questionnaire Cronbach's Alpha has been calculated (Zafiropoulos \& Vrana, 2008). If Cronbach's Alpha is higher than 0.70 the reliability is considered acceptable in social science research situations (Trochim \& Donnelly, 2006).

For the items included in the BSC questionnaire Cronbach's Alpha is equal 0.954 suggesting that the items have high internal consistency, and because Cronbach's Alpha for individual items are higher than 0.70 internal consistency is confirmed (see Appendix A).

The same test has been used for evaluation of the EFQM questionnaire. For the items in this questionnaire Cronbach's Alpha is equal 0.973 suggesting that the items have high internal consistency, and because Cronbach's Alpha for individual items are higher than 0.70 internal consistency is confirmed (see Appendix B).

By observing the average scores of the 3 parameters describing the BSC perspectives (Table 1) it is noticed that their values are quite similar and quite high. The lowest average value has the Learning \& Growth perspective indicating that this perspective, which is the basis for all other perspectives, is less developed than the other two perspectives. The high average values proceed from the fact that the sample includes organizations from a list of the 300 best organizations in Serbia.

Table 1: Descriptive statistics for BSC perspectives scores

\begin{tabular}{cccccc}
\hline Perspectives & $\mathrm{N}$ & Minimum & Maximum & Mean & $\begin{array}{c}\text { Std. } \\
\text { Deviation }\end{array}$ \\
\hline $\begin{array}{c}\text { Learning \& } \\
\text { Growth }\end{array}$ & 150 & 2.40 & 5.00 & 3.8373 & .86121 \\
$\begin{array}{c}\text { Internal } \\
\text { Processes }\end{array}$ & 150 & 2.20 & 5.00 & 3.9840 & .92032 \\
Customer & 150 & 2.20 & 5.00 & 3.9027 & .83986 \\
\hline
\end{tabular}

To test if there are significant variations in the above average values ANOVA has been used, and no significant differences between the mean scores were identified (See table 2).

Table 2: ANOVA results for BSC perspectives

\begin{tabular}{lccccc}
\hline & Sum of Squares & df & Mean Square & F & Sig. \\
\hline Between Groups & 1.620 & 2 & .810 & 1.059 & .348 \\
Within Groups & 341.811 & 447 & .765 & & \\
Total & 343.431 & 449 & & & \\
\hline
\end{tabular}

To test if there are positive correlations between the BSC perspectives correlation analysis has been performed showing that all Spearman's correlation coefficients are positive and highly significant (see table 3). The strongest relationship is between Internal Processes and the Customer perspectives (0.827). 
Table 3: Spearman's correlation coefficients for BSC perspectives $(\mathrm{N}=150)$

\begin{tabular}{cccc}
\hline Perspectives & $\begin{array}{c}\text { Learning \& } \\
\text { Growth }\end{array}$ & $\begin{array}{c}\text { Internal } \\
\text { Processes }\end{array}$ & Customers \\
\hline $\begin{array}{c}\text { Learning \& } \\
\text { Growth }\end{array}$ & 1.000 & .704 & .662 \\
$\begin{array}{c}\text { Internal } \\
\text { Processes }\end{array}$ & .704 & 1.000 & .827 \\
Customers & .662 & .827 & 1.000 \\
\hline
\end{tabular}

All Correlation coefficients are significant at the 0.01 level (2-tailed test).

According to the average scores of the 7 parameters (criteria) describing elements of the EFQM Excellence model (Table 4) it is noticed that their values are quite uniform. The lowest values are shown for Partnerships \& Resources, Customer Results and People. This means that those EFQM criteria elements are less developed compared to the other criteria and consequently managers should pay more attention to their employees and customers, but above all to their partners, especially their suppliers.

Table 4: Descriptive statistics for EFQM Excellence model criteria scores

\begin{tabular}{lccccc}
\hline & $\mathrm{N}$ & Minimum & Maximum & Mean & $\begin{array}{c}\text { Std. } \\
\text { Deviation }\end{array}$ \\
\hline Leadership & 150 & 2.40 & 5.00 & 3.9187 & .86640 \\
Strategy & 150 & 2.40 & 5.00 & 3.9040 & .95979 \\
$\begin{array}{l}\text { People } \\
\text { Partnerships }\end{array}$ & 150 & 2.40 & 5.00 & 3.8653 & .96252 \\
$\begin{array}{l}\text { \& Resources } \\
\begin{array}{l}\text { Processes, } \\
\text { Products \& }\end{array}\end{array}$ & 150 & 2.20 & 5.00 & 3.7627 & .90231 \\
$\begin{array}{l}\text { Services } \\
\begin{array}{l}\text { Customer } \\
\text { Results }\end{array}\end{array}$ & 150 & 2.40 & 5.00 & 3.8933 & .93570 \\
$\begin{array}{l}\text { People } \\
\text { Results }\end{array}$ & 150 & 2.40 & 5.00 & 3.9387 & .90039 \\
\hline
\end{tabular}

To evaluate whether differences in the average values are statistically significant ANOVA analysis has been used (Table 5).

Table 5 ANOVA results for EFQM Excellence model criteria

\begin{tabular}{lrrrrr}
\hline & $\begin{array}{c}\text { Sum of } \\
\text { Squares }\end{array}$ & \multicolumn{1}{c}{ df } & \multicolumn{1}{c}{$\begin{array}{c}\text { Mean } \\
\text { Square }\end{array}$} & \multicolumn{1}{l}{ F } & \multicolumn{1}{c}{ Sig. } \\
\hline Between Groups & 3.323 & 6 & .554 & .672 & .672 \\
Within Groups & 859.358 & 1043 & .824 & & \\
Total & 862.681 & 1049 & & & \\
\hline
\end{tabular}

According to the results from Table 5, it is concluded that there are no statistically significant differences between the average values of the EFQM model criteria.

Concerning the relationships between the criteria of the EFQM Excellence model correlation analysis has been performed (Table 6). 
Table 6 Spearman's correlation coefficients for EFQM criteria $(\mathrm{N}=150)$

\begin{tabular}{|c|c|c|c|c|c|c|c|}
\hline & Leadership & Strategy & People & $\begin{array}{c}\text { Partnerships } \\
\& \\
\text { Resources }\end{array}$ & $\begin{array}{l}\text { Processes, } \\
\text { Products \& } \\
\text { Services }\end{array}$ & $\begin{array}{l}\text { Customer } \\
\text { Results }\end{array}$ & $\begin{array}{l}\text { People } \\
\text { Results }\end{array}$ \\
\hline Leadership & 1.000 & .736 & .606 & .646 & .712 & .678 & .848 \\
\hline Strategy & .736 & 1.000 & .705 & .749 & .773 & .887 & .592 \\
\hline People & .606 & .705 & 1.000 & .711 & .762 & .677 & .735 \\
\hline $\begin{array}{l}\text { Partnership } \\
\text { \& Resources }\end{array}$ & .646 & .749 & .711 & 1.000 & .616 & .844 & .633 \\
\hline $\begin{array}{l}\text { Processes, } \\
\text { Products \& } \\
\text { Services }\end{array}$ & .712 & .773 & .762 & .616 & 1.000 & .677 & .668 \\
\hline $\begin{array}{l}\text { Customer } \\
\text { Results }\end{array}$ & .678 & .887 & .677 & .844 & .677 & 1.000 & .550 \\
\hline $\begin{array}{l}\text { People } \\
\text { Results }\end{array}$ & .848 & .592 & .735 & .633 & .668 & .550 & 1.000 \\
\hline
\end{tabular}

All correlations are significant at the 0.01 level (2-tailed).

The correlation coefficients in table 6 show that there are strong positive relations between the EFQM Excellence model criteria indicating that organizations in the sample have provided a parallel development of all critical areas of their business.

The complementarities of the BSC and the EFQM Excellence models have been confirmed through correlation analysis (see table 7). As expected, there are strong positive relations between the 3 BSC perspectives and the 7 EFQM Excellence model criteria. Similar conclusions can be drawn from other authors' research results (Lascelles \& Peacock, 1996). According to their findings, BSC implementation affects the improvement of the four result criterions of the EFQM model. The new finding here is that BSC implementation also affects the enabler criteria scores of the EFQM Excellence model.

Table 7: Spearman's correlation coefficients for the BSC and EFQM model

\begin{tabular}{lccc}
\hline & $\begin{array}{c}\text { Learning \& } \\
\text { Growth }\end{array}$ & $\begin{array}{c}\text { Internal } \\
\text { Processes }\end{array}$ & Customers \\
\hline Leadership & .694 & .710 & .724 \\
Strategy & .651 & .677 & .909 \\
People & .650 & .869 & .770 \\
Partnership \& & .736 & .697 & .785 \\
$\begin{array}{l}\text { Resources } \\
\text { Processes, Products \& }\end{array}$ & .714 & .850 & .796 \\
$\begin{array}{l}\text { Services } \\
\text { Customer Results }\end{array}$ & .726 & .642 & .841 \\
People Results & .652 & .863 & .732 \\
\hline All correlation coefficients are significant at the 0.01 level (2-tailed).
\end{tabular}

In order to analyze in detail the dependency between the EFQM Excellence model criteria and the BSC perspectives linear regression analysis has been applied with criteria of the EFQM Excellence model as the dependent variables and the BSC perspectives as independent variables. The regression analysis results are shown in Table 8.

The values of the estimated regression coefficients indicate the strength and direction of impact of the given variable on EFQM Excellence model criteria. The results are presented in 
one table only (for efficiency of the presentation), and therefore the table contains only the variables (statements) of the BSC perspectives that have significant influence on the appropriate EFQM criteria.

Table 8 Results of regression analysis

\begin{tabular}{|c|c|c|c|c|c|c|}
\hline \multirow{2}{*}{$\begin{array}{c}\text { EFQM } \\
\text { Criteria } \\
\text { (Dependent } \\
\text { Variable) }\end{array}$} & & \multicolumn{2}{|c|}{$\begin{array}{c}\text { Un-standardized } \\
\text { Coefficients }\end{array}$} & \multirow{2}{*}{$\begin{array}{c}\text { Standardized } \\
\text { Coefficients } \\
\text { Beta }\end{array}$} & \multirow[t]{2}{*}{$\mathrm{T}$} & \multirow[t]{2}{*}{ Sig. } \\
\hline & $\begin{array}{c}\text { BSC } \\
\text { Perspect. }\end{array}$ & B & $\begin{array}{l}\text { Std. } \\
\text { Error }\end{array}$ & & & \\
\hline \multirow{2}{*}{ Leadership } & $\mathrm{L} \& \mathrm{G} 4$ & .177 & .071 & .215 & 2.492 & .014 \\
\hline & L \& G 5 & .491 & .084 & .565 & 5.823 & .000 \\
\hline \multirow{2}{*}{ Strategy } & $\mathrm{L} \& \mathrm{G} 2$ & .296 & .079 & .352 & 3.726 & .000 \\
\hline & $L \& G 4$ & .313 & .079 & .344 & 3.967 & .000 \\
\hline \multirow{2}{*}{ People } & L \& G 2 & .328 & .082 & .388 & 4.011 & .000 \\
\hline & L \& G 4 & .191 & .081 & .209 & 2.359 & .020 \\
\hline \multirow{2}{*}{ People } & IP 1 & .482 & .049 & .598 & 9.754 & .000 \\
\hline & IP 3 & .184 & .075 & .208 & 2.447 & .016 \\
\hline \multirow{4}{*}{$\begin{array}{l}\text { Partnerships } \\
\text { \& Resources } \\
\text { Processes, } \\
\text { Products \& } \\
\text { Services } \\
\end{array}$} & IP 1 & .240 & .059 & .317 & 4.064 & .000 \\
\hline & IP 5 & .277 & .090 & .347 & 3.085 & .002 \\
\hline & IP 3 & .418 & .047 & .488 & 8.959 & .000 \\
\hline & IP5 & .251 & .047 & .302 & 5.349 & .000 \\
\hline \multirow{2}{*}{$\begin{array}{l}\text { Processes, } \\
\text { Products \& } \\
\text { Services }\end{array}$} & C 2 & .211 & .047 & .252 & 4.466 & .000 \\
\hline & C 4 & .542 & .047 & .633 & 11.499 & .000 \\
\hline Customer & C 2 & .214 & .029 & .291 & 7.404 & .000 \\
\hline Results & C 5 & .408 & .039 & .425 & 10.592 & .000 \\
\hline People & C 2 & .342 & .041 & .423 & 8.366 & .000 \\
\hline Results & C 3 & .447 & .041 & .474 & 10.816 & .000 \\
\hline
\end{tabular}

As was shown in Figure 1, each BSC perspective may be connected to three criteria of the EFQM Excellence model. The regression coefficients from table 8 show that certain variables of the BSC perspectives have a greater influence on the EFQM Excellence model criteria. For example, under the Learning \& Growth perspective the three variables that have the greatest influence on EFQM criteria are: LGP2 - Information flows are formal and informal, LGP4 - Employees are considered as a significant source of information and LGP5 - Employees' ethics and commitment are subject to improvement.

This means that wanted results concerning Leadership, Strategy and People criteria may be provided if the organizations are using formal and informal information flows, if employees are considered as a significant source of information, and if employees' ethics and commitment are subject to continual improvement.

On the other hand, other variables describing the BSC perspectives (in this example LGP1 - Employees are continually learning and are informed about strategy, and LGP3 There is a system for financial and non-financial incentives) are not developed or not present enough in business practices. By focusing more on those areas greater positive business performances may be expected. 


\section{Concluding remarks}

Research results have shown that relationships between the BSC perspectives and EFQM Excellence model criteria are strong. The results confirm the findings of other authors (RuizCarrillo \& Fernández-Ortiz, 2005) that the EFQM Excellence model may represent an effective tool for measuring the basis of the competitive advantage of a given organization.

The results of the research presented in this paper show how managers may discover weak points of organizational practices for attaining business excellence and consequently for improving competitiveness. Precise relationships pointed out in the research framework in figure 1 show in which BSC perspectives managers should look for improvement opportunities according to evaluations based on the EFQM Excellence model. For example, if evidence based on the EFQM Excellence model shows that the worst results are concerning Partnerships \& Resources then the causes and opportunities for improvement are related to the BSC Internal Processes perspective. Or if the evidence shows that the worst results are concerning the People criterion in the EFQM Excellence model then the causes and opportunities for improvement are related to the BSC Learning \& Growth perspective and the Internal Processes perspective and so on. Therefore, the EFQM Excellence model may be used as a road map for improvements directed towards attaining business excellence.

Although its findings coincide with the results of other authors (concerning relationships between the BSC and EFQM model), the main limitation of the research is leaving aside the financial perspective of business management. This perspective has been omitted from the research due to insufficient data. Future research should include the financial perspective of the BSC as well as financial results under the EFQM Excellence model in order to provide stronger evidence about the relationships presented in the developed framework (figure 1). Assuming that non-financial perspectives of the BSC model determine the results under financial perspective it is expected that future research will confirm the results presented in this paper. Likewise, another limitation concerns the fact that the research has been performed in a developing country (Serbia), in which the analysed business models are still a privilege of successful organizations. Therefore, future research results from developed countries or other developing countries may support the developed framework in figure 1. 


\section{References:}

Dahlgaard-Park, S.M. \& Dahlgaard, J.J. (2008). A strategy for building sustainable innovation excellence - A Danish study, in Klaus J. Zink (Ed.). Corporate Sustainability as a Challenge for Comprehensive Management, (pp. 77-94). Physica-Verlag, Heidelberg, Germany: A Springer Company.

Dahlgaard, S.M. (2008). Reviewing The European Excellence Model from a Management Control View, The TQM Journal - The Int. Review of Org. Improvement, Vol. 20 (2): 98119.

Dahlgaard, J.J., Chen, C.K, Jang, J.Y., Dahlgaard-Park, S.M. (2013). Business Excellence Models: Limitations, Reflections and Further Development. Total Quality Management \& Business Excellence, 24(5).

Davis, S., \& Albright, T. (2004). An investigation of the effect of BSC implementation on financial performance. Management Accounting Research, 15, 135-153.

Dror, S. (2008). The Balanced Scorecard versus quality award models as strategic frameworks. Total Quality Management \& Business Excellence, 19(6), 583-593.

European Foundation for Quality Management (2012). EFQM Excellence Model 2013, EFQM Publications, Bruxelles, Belgium.

Foster, S. T. (2004). Managing quality - An integrative approach. (2nd ed.). New York: Prentice Hall.

Hogue, Z., \& James, W. (2000). Linking BSC measures to size and market factors: impact on organizational performance. Management Accounting Research, 12, 1-17.

Goldratt, E., \& Cox, J. (2004). The goal - A process of an on-going improvement. (3rd ed.). Great Barrington: The North River Press.

Jou, Y. T., Hwang, C. H., Lin, W. T., \& Chen, S. C. (2007). A performance evaluation of introducing BSC to high-tech related industries in Taiwan. The International Journal of Applied Management and Technology, 5, 228-247.

Kaplan, R. \& Norton, D.P. (2000). The balanced scorecard - measures that drive performance. Harvard Business Review, January - February, Boston, MA; Harvard Business School Press.

Kaplan, R. \& Norton, D.P. (2000). The strategy-focused organization - How BSC companies thrive in the new business environment. Boston: Harvard Business School Press.

Kaplan, R. \& Norton, D.P. (2006). Alignment - Using the Balanced Scorecard to create corporate synergies. Boston: Harvard Business School Press.

Lamotte, G., \& Carter, G. (2000). Are BSC and the EFQM excellence model mutually exclusive or do they work together to bring added value to an organization? Retrieved from http://www.consultingmg.com/web/es/doc/efqmcmi.pdf

Lascelles, D., \& Peacock, R. (1996). Quality in action: Self-assessment for business excellence. Berkshire: McGraw-Hill.

Lo, T., Wong, P. S-P., \& Cheung, S-O. (2006). Using BSC approach to measure performance of partnering projects. Surveying and Built Environment, 17(1), 45-57. Retried from http://www.hkis.org.hk/ufiles/200606-trevor.pdf

Lua, D., Bettsa, A., Croom, S. (2011). Re-investigating business excellence: Values, measures and a framework. Total Quality Management \& Business Excellence, 22(12), $1263-1276$.

Ruiz-Carrillo, J. I. C., \& Fernández-Ortiz, R. (2005). Theoretical foundation of the EFQM model: the resource-based view. Total Quality Management \& Business Excellence, 16(1), 31-55. 
Santos, M. L., Alvarez, I., \& Gonzalez. L. (2007). TQM and firms performance: An EFQM excellence model research based survey. Journal of Business Science and Applied Management, 2(2), 21-42.

Shahin, A., Dolatabadi, H. R., \& Kouchekian, M. (2012). Proposing an integrated model of BSC and EFQM and analysing its influence on organizational strategies and performance: The case of isfahan municipality complex. International Journal of Academic Research in Economics and Management Sciences, 1(3), 41-57.

Trochim, W. M., \& Donnelly, J. P. (2006). The Research Methods Knowledge Base. (3rd ed.). Mason, $\mathrm{OH}$ : Thomson Custom Publishing.

Yang, C-C. (2009). Development of an integrated model of a business excellence system. Total Quality Management \& Business Excellence, 20(9), 931-944.

Wongrassamee, S., Simmons, J. E. L., \& Gardiner, P. D. (2003). Performance measurement tools: BSC and the EFQM excellence model. Measuring Business Excellence, 7(1), 1429.

Zafiropoulos, C., \& Vrana, V. (2008). Service quality assessment in a Greek higher education institute. Journal of Business Economics and Management, 9(1), 33-45.

http://proorg.fon.rs/Files/d2b60cd8-e9e0-41ce-889c.../300_Naj.doc 
Appendix A: BSC questionnaire

\begin{tabular}{|c|c|}
\hline \multirow{5}{*}{$\begin{array}{c}\text { Customer } \\
\text { Perspective }\end{array}$} & Information about customers' needs are collected \\
\hline & Product improvement is based on customers' needs \\
\hline & Relationships with customers are based on trust and commitment \\
\hline & Information about customers' satisfaction is collected \\
\hline & Customers' complaints are taken into account \\
\hline \multirow{5}{*}{$\begin{array}{c}\text { Internal } \\
\text { Processes } \\
\text { Perspective }\end{array}$} & Processes are defined and documented \\
\hline & Processes are described through flow diagram and measures are defined \\
\hline & Partnership with suppliers is based on long term relationships \\
\hline & IT systems has been established \\
\hline & Process realization is based on team work \\
\hline \multirow{5}{*}{$\begin{array}{c}\text { Learning \& } \\
\text { Growth } \\
\text { Perspective }\end{array}$} & Employees are continually learning and are informed about the strategy \\
\hline & Information flows are formal and informal \\
\hline & There is a system for financial and non-financial incentives \\
\hline & Employees are considered as a significant source of information \\
\hline & Employees' ethics and commitment are subject to improvement \\
\hline
\end{tabular}

Cronbach's Alpha for the BSC model

\begin{tabular}{cccccc}
\hline Perspectives & $\begin{array}{c}\text { Scale Mean } \\
\text { if Item } \\
\text { Deleted }\end{array}$ & $\begin{array}{c}\text { Scale } \\
\text { Variance if } \\
\text { Item Deleted }\end{array}$ & $\begin{array}{c}\text { Corrected } \\
\text { Item-Total } \\
\text { Correlation }\end{array}$ & $\begin{array}{c}\text { Squared } \\
\text { Multiple } \\
\text { Correlation }\end{array}$ & $\begin{array}{c}\text { Cronbach's } \\
\text { Alpha if } \\
\text { Item Deleted }\end{array}$ \\
\hline $\begin{array}{c}\text { Learning } \\
\text { and Growth }\end{array}$ & 7.8867 & 2.999 & .860 & .741 & .965 \\
\hline $\begin{array}{c}\text { Internal } \\
\text { Processes }\end{array}$ & 7.7400 & 2.658 & .934 & .893 & .911 \\
\hline Customer & 7.8213 & 2.943 & .922 & .881 & .921 \\
\hline
\end{tabular}


Appendix B: EFQM questionnaire

Leadership is developed and encouraged

Leaders are involved in improving management systems

Leadership Leaders are involved with customers, partners and community issues

Leaders reinforce a culture of excellence

Leaders support organizational change

Stakeholders' needs are taken into consideration

Strategy

Organization's strengths and weaknesses are taken into consideration

A clear methodology is used for developing policy and strategy

Policy and strategy are translated into action

Principles of continuous improvement are part of the strategy

Human resources are considered as a main source of competitiveness

Employees' knowledge and skills are continually developed

People Employees are empowered and involved in improvement processes

Free dialogue is encouraged between employees and managers

Employees are rewarded, recognized and cared for

The organization is committed to management of external partnerships

The organization is committed to financial resource management

Partnerships \& The organization is committed to physical assets management

Resources Technology is continually improved

The organization is committed to information and knowledge

management

Processes are systematically designed and managed

Processes, Processes are improved using innovation to meet customer needs

Products \& Customer feedback is used in the design of products and services

Services Products and services are produced, delivered and serviced to standards

Customer relationships are managed and enhanced

Data for measuring customers' satisfaction is collected

Customer

The level of customer satisfaction is continually increasing

Results

Adequacy of targets for customer satisfaction is continually reviewed

There is evidence regarding internal customer satisfaction

Cause and effect analysis is used for analyzing customer satisfaction

Data for measuring employees' satisfaction is collected

People

The level of employee satisfaction is continually increasing

Results

Adequacy of targets for employee satisfaction is continually reviewed

There is evidence regarding employee satisfaction

Cause and effect analysis is used for analyzing employee satisfaction 
Cronbach's Alpha for the EFQM model

\begin{tabular}{lccccc}
\hline \multicolumn{1}{c}{ Criteria } & $\begin{array}{c}\text { Scale Mean } \\
\text { if Item } \\
\text { Deleted }\end{array}$ & $\begin{array}{c}\text { Scale } \\
\text { Variance if } \\
\text { Item Deleted }\end{array}$ & $\begin{array}{c}\text { Corrected } \\
\text { Item-Total } \\
\text { Correlation }\end{array}$ & $\begin{array}{c}\text { Squared } \\
\text { Multiple } \\
\text { Correlation }\end{array}$ & $\begin{array}{c}\text { Cronbach's } \\
\text { Alpha if Item } \\
\text { Deleted }\end{array}$ \\
\hline Leadership & 23.1907 & 26.093 & .896 & .854 & .969 \\
\hline Strategy & 23.2053 & 25.094 & .911 & .884 & .968 \\
\hline People & 23.2440 & 25.307 & .882 & .815 & .970 \\
\hline $\begin{array}{l}\text { Partnership \& } \\
\text { Resources }\end{array}$ & 23.3467 & 25.585 & .918 & .876 & .968 \\
\hline $\begin{array}{l}\text { Processes, } \\
\text { Products \& } \\
\text { Services }\end{array}$ & 23.2160 & 25.412 & .900 & .825 & .969 \\
\hline $\begin{array}{l}\text { Customer } \\
\text { Satisfaction }\end{array}$ & 23.2827 & 26.312 & .929 & .915 & .967 \\
\hline $\begin{array}{l}\text { People } \\
\text { Satisfaction }\end{array}$ & 23.1707 & 25.846 & .887 & .849 & .970 \\
\hline
\end{tabular}

